\title{
Çocuk Acil Kliniğine göğüs ağrısı ile başvuran hastalarda akut miyokart enfarktüsünü taklit eden akut miyokardit olguları
}

\author{
Acute myocarditis that confounded by acute myocardial infarction in adolescent patients who applied \\ Pediatric emergency room with chest pain
}

Ramazan Cahit Temizkan ${ }^{1}$, Muhammet Mesut Nezir Engin², Fatih Kaya ${ }^{2}$, Mürvet Neslihan Çolak², Kenan Kocabay²

${ }^{1}$ Çocuk Acil Bilim Dalı, Tıp Fakültesi, Düzce Üniversitesi, Düzce, Türkiye

${ }^{2}$ Çocuk Hastalıkları Ana Bilim Dalı, Tıp Fakültesi, Düzce Üniversitesi, Düzce, Türkiye

\section{ÖZET}

Göğüs ağrısı, ST segment elevasyonu ve kardiyak enzimlerde yükselme ile gelen çocuk hasta grubunda kardiyak kökenli hastalık ve aile hikâyesi yoksa düşünülecek ilk tanı miyokardittir. Ancak miyokardit bazen akut miyokart enfarktüsü gibi bazı hastalıklarla karışabilir. Elektrokardiyografi (EKG) bulguları farklı olmasına rağmen, bazen akut miyokart enfarktüsü ve akut miyokardit birbirini taklit edebilir. Bu iki hastalı̆̆ın tedavi ve prognozu birbirinden tamamen farklıdır. Ayırıcı tanıya varmak hayat kurtarıcıdır. Bundan dolayı göğüs ağrısı ile başvuran, EKG de ST-T değişiklikleri mevcut olan ve kardiyak enzimlerde yükselme saptanan hastaların ayırıcı tanısı, tedavisi ve takibi için çocuk kardiyolojisi olan merkeze acilen sevki gereklidir. EKG’de spesifik ST-T değişiklikleri, göğüs ağrısı olan ve kardiyak enzimlerde yükselme olan 14 ve 16 yaşında miyokardit tanısı konulan iki hastayı sunduk.

Anahtar kelimeler: Miyokarditler, adölesan, göğüs ağrısı

\begin{abstract}
In children patients with chest pain, ST segment elevation and increase in cardiac markers, myocarditis must be the first diagnosis to consider if there is no cardiac disease history. Sometimes myocarditis can be confounded by some diseases like acute myocardial infarction. Although the electrocardiographic (ECG) signs are different, acute myocardial infarction and acute myocarditis can be duplicate occasionally. Treatments and prognosis of these two diseases are totally different. Differential diagnosis is life saver in these situations. Therefore, if ST-T changes in ECG and increased cardiac markers are assessed in patients with chest pain; differential diagnosis, treatment and referring the patient to a pediatric cardiology department for observation are mandatory. We introduce two patients aged 14 and 16, who have chestpain, spesific ST-T changes and increase in cardiac markers.
\end{abstract}

Keywords: Myocarditis, adolescent, chest pain

Başvuru / Submission: Mart / March 01, 2017

Kabul / Acceptance: Nisan / Apr 20, 2017

Yazışma / Correspondence: Dr. Ramazan Cahit Temizkan, Düzce Üniversitesi Tıp Fakültesi Çocuk Acil B.D. Düzce, Türkiye

\begin{tabular}{|l|l|l|}
\hline E-MAIL & ORCID ID & DOI \\
\hline @rctemizkan@hotmail.com & iD orcid.org/ & doi 10.22391/920.295559 \\
\hline
\end{tabular}

Atıf / Cite: Temizkan RC, Engin MMN, Kaya F, Çolak MN, Kocabay K. [Acute myocarditis that confounded by acute myocardial infarction in adolescent patients who applied Pediatric emergency room with chest pain].Fam Pract Palliat Care. 2017;2(2):18-21 


\section{GİRIŞ}

Çocuk acil servisinde göğüs ağrısı ile başvurularla sık karşılaşılmaktadır. Çocuklarda göğüs ağrısı sıklıkla kalp dışı nedenlere bağlıdır. Fakat kardiyak kökenli göğüs ağrısı, hayati risk taşıdığından tanınması son derece önemlidir. ${ }^{1}$

Miyokardit; enfeksiyöz, bağ doku, granülomatöz, toksik veya idiyopatik nedenlerle miyokardın inflamasyon, nekroz veya miyositolizidir. Viral miyokarditli hastaların çoğunda olay geçici hafif bir inflamasyondan ibarettir, tam olarak iyileşme olur. Bununla birlikte bazı hastalarda kalıcı veya ilerleyici bir kardiyomegali, subakut veya kronik miyokardit ve sonuç da DKMP (Dilate kardiyomyopati) tablosu gelişir. Nadiren de olsa en önemli komplikasyonu ölümdür. Ölüm nedenleri arasında ritim ve iletim bozuklukları, kalp yetmezliği ana etkenlerdendir. Miyokart enfarktüsleri ise önemli mortalite ve morbiditeye yol açan acilen müdahale edilmesi gereken daha ciddi klinik durumlardır. Akut miyokart enfarktüsleri ve miyokardit bazen, kliniği, troponin değerinde yükselme ve elektrokardiyogrfi (EKG) bulguları birbirine benzeyebilir, bundan dolayı ayırt etmek güçleşir.

Tedavi ve takiplerinin yapılabilmesi için tanının kesinleşmesi önem arz etmektedir. Özellikle acil kliniklerde gögüs ağrısıyla başvuran hastalarda troponin değerinde yükselme ve EKG deki ST yükselmesi ilk planda miyokart enfarktüsü olarak değerlendirilir ve yanlış tedavi uygulanmasına sebep olabilir. Acil servis şartlarında ayırıcı tanı yapma güçlüğü ve hastaya erken müdahalenin yaşam kurtarıcı olması nedeni ile hastanın ivedilikle çocuk kardiyolojisine sevki uygundur.

Çalışmamızda EKG'de spesifik ST-T değişiklikleri, göğüs ağrısı olan ve kardiyak enzimlerde yükselme olan, miyokardit tanısı konulan, 14 ve 16 yaşında iki hastayı sunduk.

\section{OLGU SUNUMU}

\section{Olgu 1}

16 yaşında erkek hasta, baskı tarzında göğüs ağrısı, çene ve sol kolda uyuşma başlaması nedeniyle acil servisimize başvurdu. Öyküsünden 10 gün önce gastroenterit ve üst solunum yolu enfeksiyonu semptomlarının olduğu, iki gün önce hafif gögüs ağrısının olduğu, mide bulantısının başladığı, aile sağlığı merkezine başvurduğu, viral enfeksiyon tanısı konularak semptomatik tedavi verildiği öğrenildi.

Özgeçmişinde kardiyak risk faktörleri, ailesinde erken koroner arter hastalığı, uyuşturucu madde veya ilaç kullanım öyküsü yoktu.

Hastanın yapılan fizik muayenesinde bilinç açık, oryante ve koopere, kan basınc1 121/72 mmHg, nabız 138/dakika düzenli olan bir sinüs taşikardisi mevcuttu, diğer sistem muayeneleri ise doğal saptand1. Vücut 1sısı normaldi (timpanik: $37,1^{\circ} \mathrm{C}$ ). PAakciğer grafisi normal olarak değerlendirildi. Acil serviste çekilen EKG de ilk beş derivasyonda (V1-V5) 1,5 mm ST yükselmesi mevcuttu (Resim 1 ve Resim 2).

Acil serum biyokimyasal tetkiklerinde; kardiyak enzimler; Troponin I: 41 ng/ml (0,02 - 0,06), CK: 1009 mg/dl (0 - 190) ve CK-Mb: 132,5 IU/L (0 - 25) değerleri saptand1. Hastanın diğer tetkiklerinde hemoglobin: $14,7 \mathrm{~g} / \mathrm{dL}$ (10 - 17), lökosit: $12100 / \mathrm{Ul}(3000$ - 15000) ve C reaktif protein (CRP): 14,5 $\mathrm{mg} / \mathrm{dL}(0-0,5)$ olarak saptand. Protrombin zamanı, INR vb. tetkikleri normal saptand1.

Hasta dış merkeze Çocuk Kardiyolojisine sevk edildi. Dış merkezde çekilen kalbin magnetik rezonansında sol ventrikül segment 14'te T2 sinyal artışı ve kontrast tutumu tespit edilmişti. Subendokardiyal alan korunduğu için miyokardit ile uyumlu değerlendirilip akut miyokardit tanısı konularak antiinflamatuar tedavi başlanmıştı. EKG bulgusu düzelen, kardiyak enzimleri ve semptomları gerileyen hasta tedavisi verilip kontrole gelmek üzere taburcu edilmişti.

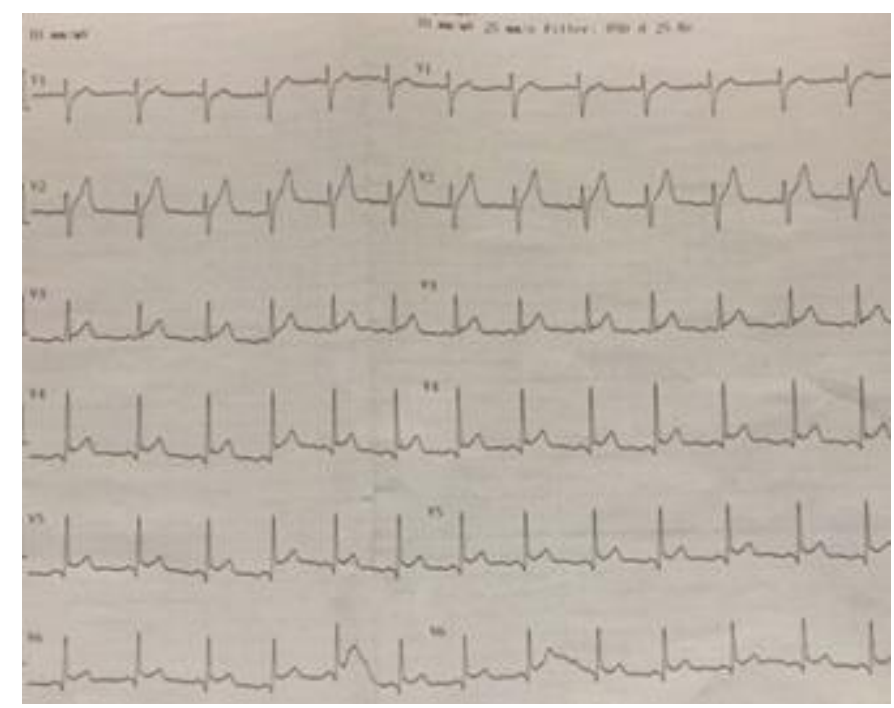

Resim 1. Göğüs derivasyonlarındaki ST değişiklikleri (1.olgu)

\section{Olgu 2}

14 yaşında erkek hasta, göğüs ağrısı şikâyeti nedeniyle acil servisimize başvurdu. Özgeçmişinde; kardiyak risk faktörleri, ailesinde erken koroner arter hastalığı, uyuşturucu madde veya ilaç kullanım öyküsü yoktu.

Hastanın yapılan fizik muayenesinde bilinç açık, oryante ve koopere, kan basınc1: 128/80 mmHg, nabız: 115/dakika düzenli, kalp ve diğer sistem muayeneleri doğal saptandı. Vücut 1sısı normaldi (timpanik: $36,2^{\circ} \mathrm{C}$ ). Pa akciğer grafisi normal olarak değerlendirildi. 
Acil serviste çekilen EKG de V5, V6 derivasyonlarda 1,5 mm ST yükselmesi, aVL, V2 derivasyonlarda $1 \mathrm{~mm}$ ST çökmesi mevcuttu (Resim 3). Kardiyak enzimler Troponin I: $>50.000 \mathrm{ng} / \mathrm{ml}(0,02$ - 0,06), CK: $2035 \mathrm{mg} / \mathrm{dl}$ (0 - 190) ve CK$\mathrm{Mb}:$ 159,6 IU/L (0 - 25) değerleri saptandı. Hastanın diğer tetkiklerinde hemoglobin: $13,9 \mathrm{~g} / \mathrm{dL}(10$ - 17), lökosit: 12600/Ul (3000 - 15000) ve CRP: 23,8 mg/dL (0 - 0,5) olarak bulundu. Protrombin zamanı, INR vb. tetkikleri normal saptand1.

Hasta dış merkez çocuk kardiyolojisine sevk edildi. Dış merkezde bu bulgular ile akut miyokardit tanısı konulup anti inflamatuar tedavi başlanmıştı. EKG bulgusu düzelen, kardiyak enzimleri düşen ve semptomları gerileyen hasta tedavisi verilip kontrole gelmek üzere taburcu edilmişti.

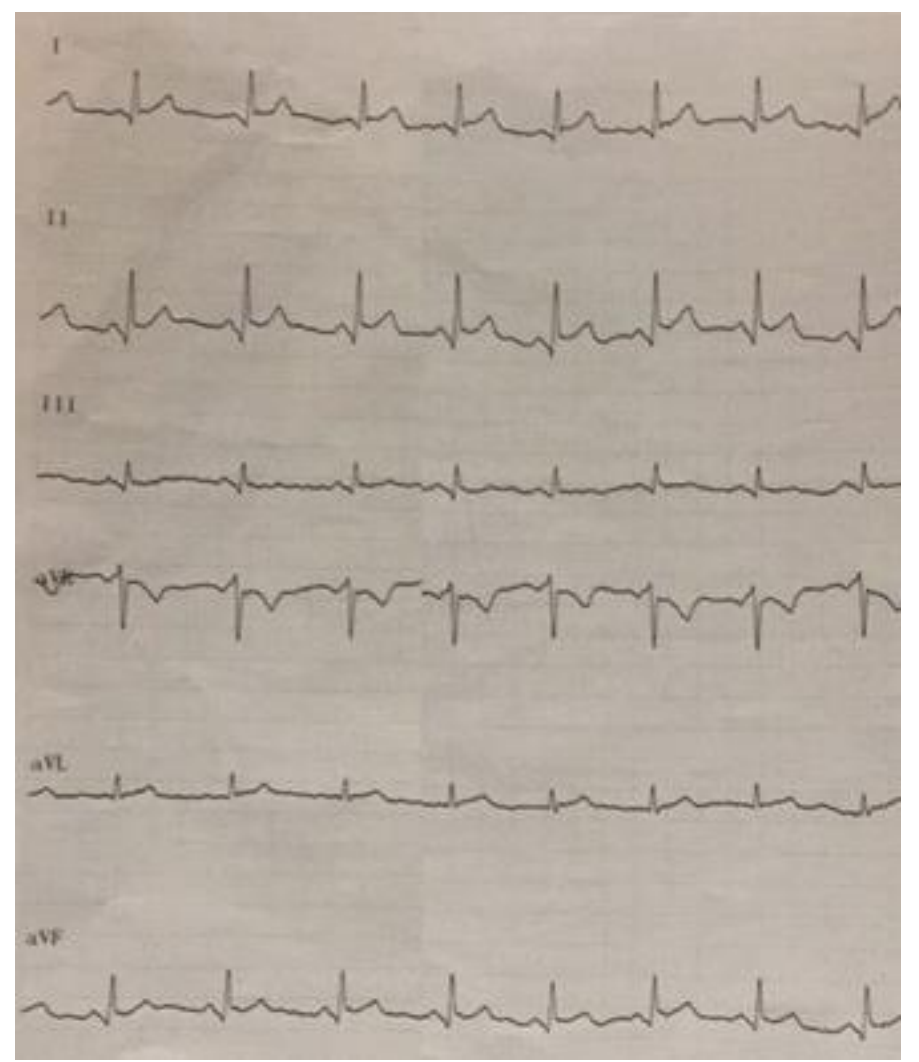

Resim 2. Ekstremite derivasyonlarındaki ST değişiklikleri (1.olgu)

\section{TARTIŞMA}

Çocuk hasta grubunda hikâyede göğüs ağrısı, viral üst solunum yolu enfeksiyonu, gastroenterit öyküsünün varlığı, EKG deST$\mathrm{T}$ değişiklikleri ve kardiyak enzimlerde yükselme akut miyokardit tanısına yönlendirebilir. Elektrokardiyografi bulguları farklı olmasına rağmen, bazen akut miyokart enfarktüsü ve akut miyokardit birbirini taklit edebilir.

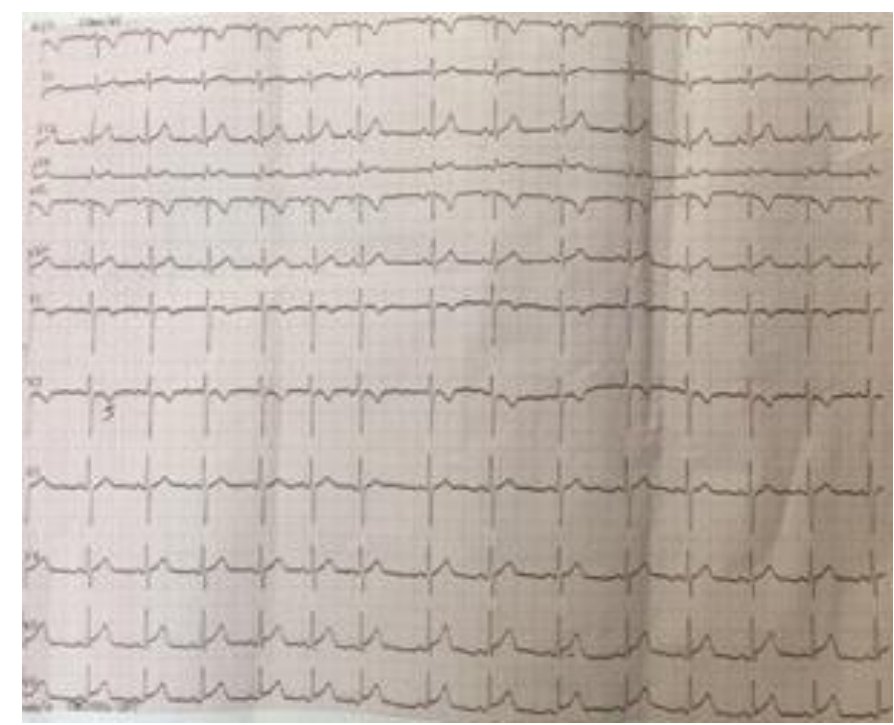

Resim 3. Tüm derivasyonlardaki değişiklikler (2.olgu)

Akut miyokart enfarktüsünde ve miyokardit'de ayırıcı tanı için acil değerlendirmede göğüs ağrısı şikayetini sorgulama ve EKG çok önemlidir. Genellikle ST yükselmeli akut miyokart enfarktüsünde sıkıştırma ve baskı şeklinde, sırta, sol kola yayılan göğüs ağrısı görülmektedir. Miyokarditte ise batma şeklinde ağrı görülmektedir. Miyokarditte genelde EKG'de spesifik olmayan ST, T değişiklikleri veya miyoperikardit olgularında tüm derivasyonlarda ST yükselmesi gözlenirken, tersi yönde ST çökmesi gözlenir. Enfarktüs bölgesinde EKG'de ST yükselmesi, diğer derivasyonlarda tersi yönde ST çökmesi gözlenir. EKG'de ST yükselmesi kalp hastalıklarının dışındaki diğer durumlarda da görülebilir. (Pulmoner emboli, subaraknoid kanama, pankreatit, fokal miyokarditle seyreden romatoid artrit $\mathrm{vb}.)^{3-4}$

Miyokarditin klinik tanısında, özellikle viral miyokarditlerde, öncelikle viral enfeksiyon gastro intestinal veya üst solunum yolu infeksiyon bulguları başlar sonra günler haftalar sonra göğüs ağrısı benzeri semptomlar gelişir (konjestif kalp yetersizliği, aritmi, trombo-emboli bulguları) bazen de ani ölüm gibi seyrek ama ciddi bulgular görülebilir. Ancak miyokarditte kardiyak fonksiyonların korunduğu halsizlik, nefes darlığı, batma şeklinde göğüs ağrısı ve çarpıntı gibi spesifik olmayan şikayetler'de görülebilir. ${ }^{5}$

Miyokardit seyrinde miyokart enfarktüsü, ventriküler mikro anevrizma, ventriküler taşikardi atağı gibi klinik durumlarda gözlenebilir. Laboratuar tetkiklerinde, EKG'de genelde spesifik olmayan ST-T değişiklikleri görülür. Göğüs röntgeninde kalp büyüme bulguları, kan sayımında lökositoz, miyokart nekrozisinin serum biyokimyasal tetkiklerinde, miyokart enzimleri genelde yükselmez, miyokardit olgularının \%10'un altında kardiyak enzimler (kreatinkinaz (CK)) yükselmesi görülür. Miyokarditin spesifik bir tedavisi yoktur. Yatak istirahatı, kalp yetersizliği ve aritmi tedavisi şeklindedir. ${ }^{7}$ 
Miyokardit olgularında DKMP, kalp yetmezliği ve ani ölüm gibi komplikasyon gelişebileceği için yakın izlemi gereklidir. ST yükselmeli miyokart enfarktüslerinde hızlı bir şekilde tanıya ulaşıp, hızlı bir şekilde tedavi başlanması gerekmektedir.

Miyokarditte, EKG'de ST yükselmesi nekroza bağlı olarak görülebilir, hatta akut ST yükselmeli miyokart enfarktüsünü taklit edebilir. Literatürde akut ST yükselmeli miyokart enfarktüsüne benzeyen bölgesel miyokardit olguları da mevcuttur. Bunlar arasında tanıya ulaşmak için, çok kesitli bilgisayarlı tomografi, magnetik rezonans inceleme, koroner anjiyografi ve endomiyokardiyal biyopsi gibi tetkikler sonrası ayırıcı tanıya ulaşılmıştır. ${ }^{7-8}$

Bizim vakalarımızda da ateroskleroz risk faktörleri olmayan genç iki hastada, göğüs ağrısıyla birlikte EKG'de spesifik STT değişiklikleri ve kardiyak enzimlerde de yükselme saptanıp ST yükselmeli miyokart enfarktüsü ön tanısı konulup ileri takip ve tedavi için dış merkeze sevk edilmişti. Dış merkezde yapılan değerlendirmede, kardiyak enzimler ve EKG bulguları ST yükselmeli miyokart enfarktüsüne benzerlikler mevcut olan hastalara akut miyokardit tanısı konulmuştu. Bir hastamıza dış merkezde yapılan magnetik rezonans tetkiki ile tanı kesinleştirilmişti. Bir hastamızda viral gastroenterit öyküsü mevcut olduğundan viral miyokardit olabileceği öngürüldü. İki hastamızda da CRP artışı dikkatimizi çekmiştir. İki hastamızın da anti-inflamatuvar tedavi ve yatak istirahati ile klinik durumları iyileşmiş, EKG ve kardiyak enzimleri düzelmiştir. Hastamız palyatif tedavi (istirahat ve anti-inflamatuvar tedavi) ile iyileştiğinden ileri tetkike ihtiyaç duyulmamıştır.

\section{SONUÇ}

Göğüs ağrısı, kardiyak enzimlerde yükselme ve ST segment elevasyonu ile gelen hastalarda düşünülecek ilk tanı aciliyeti açısından düşünüldüğünde akut miyokart enfarktüsüdür. Ancak akut miyokart enfarktüsü bazen miyokardit gibi bazı hastalıklarla karışabilir. Çocuk hasta grubunda hikayede göğüs ağrısı, viral üst solunum yolu enfeksiyonu, gastroenterit öyküsünün varlığı ve bizim olgularımızda olduğu gibi CRP artış1 miyokardit lehine düşünülse de, akut miyokart enfarktüsü ve miyokardit ayrımı çok kesitli bilgisayarlı tomografi, magnetik rezonans inceleme, koroner anjiyografi ve endomiyokartiyal biyopsi gibi tetkikler sonrası ayırıcı tanıya ulaşılır. $\mathrm{Bu}$ iki hastalığın tedavi ve prognozu birbirinden tamamen farklıdır. Ayırıcı tanıya varmak ve koroner anjiografi kararı verebilmek hayat kurtarıcıdır. Bu sebeplerden dolayı tanının kesinleşmesi, miyokardit veya akut myokard enfarktüsü olgularında prognoz izlemi ve gerekli durumlarda müdahale edebilme açısından hastaların hastanede izlemi gereklidir.

Birinci basamakta çalışan hekimler açısından göğüs ağrısı ile başvuran, EKG de ST-T değişiklikleri mevcut olan ve kardiak enzimlerde yükselme saptanan hastaların ayırıcı tanısı, erken tedaviye başlanması ve takibi için çocuk kardiyolojisi olan merkeze acilen sevki gereklidir.

Çıkar ilişkisi: Yoktur.

Finansal destek: Yoktur.

\section{KAYNAKLAR}

1. Selbst SM, Ruddy RM, Clark BJ, HenretigFM, Santulli T Jr. Pediatricchestpain: a prospectivestudy. Pediatrics1988;82(3):319-23.

2. Liu P, Martino, Opavsky MA, Penninger J. Viral myocarditis: balance between viral infection and immune response. Can J Cardiol 1996;12(10):935-43.

3. Wu CH, Sung SH, Wu TC. Focal myocarditis mimicking myocardial infarction in a patient with rheumatoid arthritis. Clin Rheumatol 2009;1:23.

4. Falterman TJ, Martinez JA, Daberkow D, Weiss LD. Pulmonary embolism with ST segment elevation in leads V1 to V4: case report and review of the literature regarding electrocardiographic changes in acute pulmonary embolism. J EmergMed 2001;21:255-261.

5. Şatıroğlu Ö, Vural M, Uyar İ, Meriç M. Akut ST yükselmeli miyokard infarktüsüne benzeyen bölgesel miyokardit. Nobel Med 2011; 7(1): 119-123

6. Zipes PD, Libby P, Bonow RO, Braunwald E. Braunwald's Heart disease a textbook of cardiovascular medicine. Myocarditis. 7 th edition. CH 60, P. 1697-1700.

7. Testani JM, Kolansky DM, Litt H, Gerstenfeld EP. Focal myocarditis mimicking acute ST-elevation myocardialinfarction: diagnosis using cardiac magnetic resonance imaging. TexHeartInst J 2006; 33: 256-259.

8. Pomara C, Villani A, D'Errico S, et al. Acute myocarditis mimicking acute myocardial infarction: a clinical nightmare with forensic implications. Int J Cardiol 2006; 10:119-121. 